\title{
The Absence of Cremation Sites within Cemeteries of the Przeworsk and Wielbark Cultures in the Roman Period in Great Poland
}

\author{
Daniel Żychliński \\ THOR Archaeological Research Gniezno - Poland \\ *Corresponding author: daniel_zychlinski@o2.pl
}

Copyright (C) 2013 Horizon Research Publishing All rights reserved.

\begin{abstract}
The main purpose of this paper is to explain the absence of cremation sites within cemeteries of the Przeworsk and Wielbark communities in Great Poland region located in western part of Poland. First of mentioned cultures existed there from the end of II century $\mathrm{BC}$ to the beginning of VI century AD (125/100 BC-500/510 AD). Second of them - the middle ofthe I century AD to $2^{\text {nd }}$ half of the III century AD (40/50 AD-260/270 AD). Great Poland comprised part of Barbaricum, which was not very closely connected with the Roman Empire, but there is much evidence for contacts between those two regions. Based on current research connected with rites of passage observed in burial rituals of those communities, it seems obvious that cremation places - ustrina were located out of cemeteries and settlements in separated places near banks of the rivers, because they appertained to liminal zone. But busta located within necropolis were in fact graves and belonged to sacrum zone.
\end{abstract}

Keywords Burial Rite, Central Europe, Roman Period,
Ustrina

\section{Introduction}

The present contribution proposes a hypothesis, based on knowledge derived from archaeological and anthropological evidence, aiming to explain the absence of cremation sites within cemeteries of the Przeworsk and Wielbark communities in Great Poland.

Great Poland is located in western part of Poland and it borders to Brandenburg in eastern Germany (Figure 1).

The archaeological sites discussed below are all situated in the territory of Great Poland, but the Przeworsk culture cemeteries are concentrated mostly at south of this region and the Wielbark culture necropolis are concentrated in the north (Figure 2).

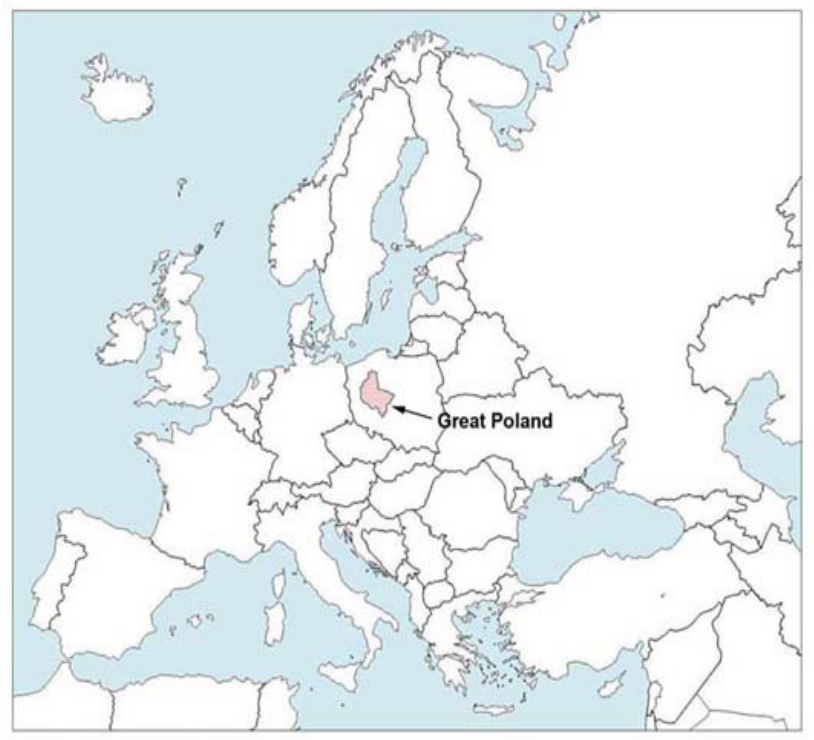

Figure 1. Location of Great Poland in Europe 


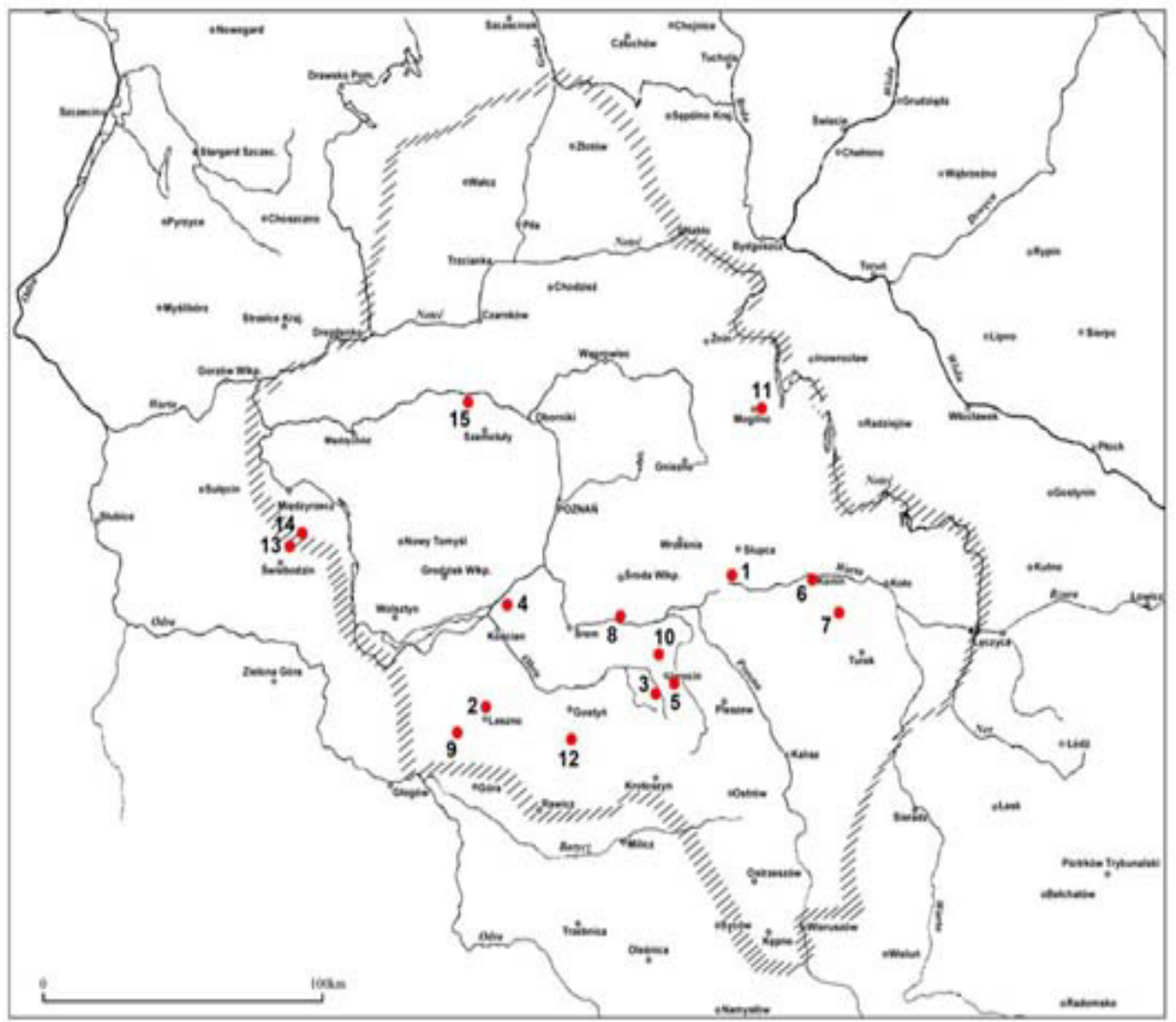

1. Ciążeń, pow. Słupca, woj. wielkopolskie, stan. ?;

2. Gronówko, pow. Leszno, woj. wielkopolskie, stan. ?;

3. Kapalica, pow. Jarocin, woj. wielkopolskie, stan.?;

4. Roszkowo, pow. Kościan, woj. wielkopolskie, stan. I;

5. Siedlemin, pow. Jarocin, woj. wielkopolskie, stan. ?;

6. Konin, miasto powiatowe, woj. wielkopolskie, stan. B

7. Kuny, pow. Turek, woj. wielkopolskie, stan. 4;

8. Mlodzikowo, pow. Środa Wielkopolska, woj. wielkopolskie, stan.1

9. Olbrachcice, pow. Nowa Söl, woj. lubuskie, stan. 4;

10. Osiek, pow. Jarocin, woj. wielkopolskie, stan. 10;

11. Świerkówiec, pow, Mogilno, woj. kujawsko-pomorskie, stan. 1 i 2 ;

12. Wymyslowo, pow. Gostyń, woj, wielkopolskie, stan. I;

13. Jordanowo, pow. Świebodzin, woj. lubuskie, stan. 12;

14. Brojce, pow. Międzyrzecz, woj. lubuskie, stan. ?;

15. Slopanowo, pow. Szamotuly, woj. wielkopolskie, stan. I;

Figure 2. Locations discussed archaeological sites in Great Poland

Great Poland comprised part of Barbaricum and was not very closely connected with the Roman Empire. However, there is much evidence for contacts between local societies and Roman merchants.

The Przeworsk culture, which is equated with the ancient Vandals, inhabited territories of Great Poland from the end of second century $\mathrm{BC}$ to the beginning of sixth century $\mathrm{AD}$ (125/100 BC- AD 500/510). The Wielbark communities which were with great probability the Goths, appeared in Great Poland in the middle of the first century AD and moved out to Black Sea territories in 2nd half of the third century AD (AD 40/50-AD 260/270). Both of them practised cremation of their deceased, but Wielbark culture populations also practised inhumation in nearly $50 \%$ of all burials [1].

It should be emphasised, that the phenomenon of absent cremation sites occurs frequently in the whole area inhabited by Przeworsk and Wielbark cultures communities, and, which is also of great significance, is recognisable in various regions of Europe and Asia as well. In contrast to the absence of cremation sites on cemeteries of both cultures, cremation burials are actually quite common. It seems that features that have been discovered in various necropolises and so far interpreted as ustrina must have played more complex role, something which has been suggested elsewhere in the literature on the subject $[2,3]$. 
The hypothesis discussed below aims to explore this possibility further, assuming that the sites where the body of the dead was transformed into ashes were located somewhere between the worlds of the living and the dead. They existed between sacrum and profanum, and it was exactly there where the climax of the rites of passage took place $[4,5]$.

The above description perfectly fits the typical tripartite scheme of rites of passage [6]. According to this concept a cremation, and thus the place at which it took place (a pyre), were excluded from every-day and sacral lives. In a settlement the dead were isolated from the rest of the living, while at a cemetery the dead were welcomed by the deceased ancestors and reintegrated with the living $[4,5]$. These two stages were separated by a transition phase - a liminal state, the cremation process itself [7], leading to the creation of a new personality of the dead [5]. From that moment the dead became friendly and protective.

The above assumption explains and validates the absence of cremation sites, both in necropolises and within settlements, and consequently also the absence of recorded cremation sites in general. Such sites, most probably, were located far from, or at least separate from living areas as well as burial sites - out of the settlements and cemeteries, hence in the areas being located and excavated only by chance (such as those accompanying investments and constructions - [8]). Moreover such sites might also be very small and isolated, or leave only minimal archaeological trace that is unlikely to be detected by some survey techniques.

As yet, only few researchers have adopted this approach and interpreted the scarce number of cremation sites compared to the high number of cremation burials in the above suggested way. An interesting approach is represented by the work of Kempisty [9], who looked for analogies in burial rites of modern inhabitants of India. The other voice in the discussion comes from Jaskanis [10], who only went as far as noting the absence of cremation sites, but did not give further explanations.

It should be mentioned, however, that the phenomena de-scribed above, have been observed not only in Poland, but are known elsewhere and are widespread. Comparison might be drawn, for example, with some burial ceremonies of Roman period Italy, where the tripartite passage rites, as described above, were clearly seen in some periods and emphasised by some people [11]. Also in this context, the cremation took place outside the seats of the dead and the living. Moreover, separation of cremation spaces was also legalised [5]. The dead were cremated outside the city walls, as had been mentioned already by Cicero (De Legibus 2.58), a notion cited on the 10th board of the Law of the Twelve Tables [12]. The same rule was apparently obligatory in the colonies, as reflected in their legislations, e.g. in lexColoniaeGenetivaeIuliaeseuUrsonensis [12].

Referring to cultural anthropology, it is possible to list some modern examples of burial practices, where "multiple-use" ustrina are localised over the rivers or lakes, separated from burial sites and dwelling areas. It is perfectly illustrated by so called Ghats of Varanasi in India - the places of a "permanent" cremation of the dead of the followers of Hinduism, whose ashes are poured into the sacred river - Ganges $[13,14,15]$.

\section{Archaeological Evidence}

The cemeteries of the Przeworsk communities in Great Po-land have provided researchers with numerous features commonly interpreted as ustrina. In the literature on the subject, all of the non-burial features with the slightest traces of burning found in necropolises have been interpreted as such $[1,16]$.

According to the definition offered by Jerzy Szydłowski [17] an ustrinum must have impressive dimensions, at least similar to height of an adult person. It should contain abundant charcoal remains of burned timber or burning, and the soil underneath should have features typical for a high temperature environment. The fill of ustrina, theoretically, should also contain a small number of cremated bones, left by the participants of a funeral, as well as burned and often fragmented grave goods [17]. Such a place was constantly used as a cremation site where either individuals or groups of the dead were cremated, but never as a grave [16].

However, another category with similar features has also been recognised, not ustrina, although the dead were cremated there - namely busta. The latter differ from the former in that they played both roles at the same time - after cremation a pyre site became a grave.

The first information about busta comes from the second century AD. Roman grammarian SextusPompeius Festus de-scribed them as a place where the deceased is both burned and buried [18].

Therefore, the fill of a bustum burial should, in theory, contain a complete burned skeleton and also, crucially, grave goods [16]. Intentionally deposited grave goods seem the most important feature that differentiates both types of cremation sites from each other, although if the grave goods were scanty, a proper recognition and interpretation of the site may be a serious problem.

On the other hand, completeness of a cremated body is problematic, even though the amount of bones retrieved is expected to weigh, for one adult individual, between $1600-2000 \mathrm{~g}[16,19,20]$, because in bustum burials with ditches (pyre sites with under-pyre pits) it was possible to monitor the cremation process - adding fuel, and hence increasing effectiveness of the cremation, which was reflected in the weight of burned bones.

Archaeological interpretations provide evidence in some opposition to that provided by anthropological data, proven also by experimental cremation of the human skeleton. What is more important, these experiments revealed that: "When the timber burned down and the pyre cooled down (...), it was not a problem to take out fragmented bones. It was easy to find even the smallest fragments of a skeleton..." [20]. The 
same results of experiments were described by other researchers [19]. This observation contradicts assumptions that the absence of the parts of skeleton in a cinerary urn or a fill of a burial was caused by careless selection of its burned parts. It may be also assumed that picking up burned artefacts from the site of a fire could not have be a problem for the participants of the ceremony, and missing a big artefact, especially that such as a sword [21], was almost impossible! Then, it might be assumed that if the fill of the feature localised within the cemetery and described as an ustrinum included also grave goods and human bones, it is highly probable that it represented not an ustrinum but a burial localised at the cremation site, thus a bustum.

Of a great importance is also a deposition environment of cremated remains, because the chemical conditions of soil in which the cremated bones were burry could contributed time of their decomposition and in ending result absolutely vanishing [16].

Here, the evidence from Great Poland interpreted by their discoverers as cremation sites will be discussed: first those of the Przeworsk, then the Wielbark cultures. These features have been classified on the basis of the above definitions. Unfortunately, in many cases the available descriptions in published literature have been scarce or incomplete, which makes, for instance, their dating inaccurate. It should be emphasised, that the evidence from the two below discussed cultures, despite being of the same period, is very different. For Przeworsk communities there was plentiful evidence for cremation sites located in cemeteries, for Wielbark it was comparatively little. The most important is question concerns why that situation occurred and whether the answer might be found in further studies which take account of the problematic discussed above.

In the cemetery in Ciażeń, county Słupca, there have been recognised several features, 2 to $5 \mathrm{~m} 2$ in size, sunken to a depth of about $0.8 \mathrm{~m}$, with a five-to-eight-centimetre-thick layer of burning. The bedrock was also burned. In some cases grave goods have been found [22]. Highly probably, according to the classification by Józefów [16], they might be interpreted as bustum burials with under-pyre pits or Grubenbusta (from German; [19]).

Much more difficult appears to be an interpretation of a feature discovered in Gronówko, county Leszno, described as "a level of charcoal and sherds of pottery", by the author of the discovery and interpreted as a cremation site [23]. Unfortunately, as the description of the discovery is only fragmentary, its reinterpretation seems difficult. It is also possible that the feature might not have been connected with the cemetery at all.

"Typical" bustum burials were those covered by mounds the Siedlemin-type barrows in Kapalica, Roszkowo and Siedlemin, county Jarocin. A pyre site in all these cases func-tioned also as a site of burial [24]. To stabilise the ground underneath the pyre its surface was leveled (barrow VI) and covered with clay, which became heated in the process of cremation and produced a kind of casting. Such a type of strongly fired construction $5 \times 2.5-3 \mathrm{~m}$ in size, was discovered under barrow I in Siedlemin [24]. Under barrow IV there was unearthed a circular area with the remains of a cremation layer of $3-5 \mathrm{~m}$ in radius [24], while under barrow $\mathrm{V}$ a quadrilateral one, $5 \times 4.5 \mathrm{~m}$ in size was identified. The area to the N-E was also burned, which might suggest, as the author of the monograph does, that during the cremation an S-W wind was blowing [24]. Barrow VI has also provided similar observations [24]. There is no doubt that the discoveries described above should be interpreted, according to Józefów, as surface busta [16], known as Flächenbusta [19]. Their impressive size might have resulted from intentional parting of ashes [16].

In Konin, county loco, site B, there was a feature unearthed in the cemetery consisting of a layer of charcoal and burning, $25-30 \mathrm{~cm}$ thick, with numerous sherds of pottery and 2 buckles [25]. According to its description, the feature might be interpreted as a bustum burial with under-pyre pit in Józefów's classification [16] or Grubenbustum [19]. Although there were no cremated bones, their absence might have resulted from the conditions of a cremation process itself as well as from post-depositional processes.

Site 4 in Kuny, county Turek, provided researchers with a unique feature that has been interpreted by the author of the excavation and publication as an ustrinum. It was $2.73 \times 2.22$ $\mathrm{x} 0.87 \mathrm{~m}$ in size, and its fill contained charcoal remains, ash, and 8 big stones. What is more, tens of burned sherds of pottery have been found, as well as numerous unique metal artefacts (shield grips and bosses, swords, sword scabbard fittings, spear- and arrowheads, shoes) and $10 \mathrm{~g}$ of cremated human bones [21]. This description quite clearly suggests interpretation of the feature as a bustum burial with under-pyre pit, according to Józefów [16] or Grubenbustum [19]. Such an interpretation seems even more credible, as it has been verified in experimental cremations (see above).

In Młodzikowo, county ŚrodaWielkopolska, there have been shallow pits discovered up to $10 \mathrm{~cm}$ in depth, $2 \mathrm{x}$ $1-1.5 \mathrm{~m}$ in size, with the fill containing burned soil, sand, charcoal, a small number of cremated human bones, and pumice-like fragments of pottery. Such features were located between burials [26]. It seems that they also might be interpreted as bustum burials with under-pyre pits, by Józefów [16] or Grubenbusta [19]. Their depth was quite small, although it might have resulted from natural agents or subsequent intensive farming.

In Olbrachcice, county Wschowa, there have been numerous features unearthed, of non-defined use. At least two others have also been found, elongated, more than $2 \mathrm{~m}$ long and $1 \mathrm{~m}$ wide. Their fill contained a substantial amount of charcoal and several stones [27], as well as heated sand, which led to their interpretation as cremation sites. They might be also in-terpreted as bustum burials with under-pyre pits, by Józefów [16] or Grubenbusta [19].

In Osiek, county Jarocin, within a widespread area $(15 \mathrm{x}$ $10 \mathrm{~m}$ ), there has been unearthed a slightly sunken layer of burning with bones and several pottery and metal artefacts. The researcher of the site suggested that an ustrinum might have existed there [28]. However, it seems also possible that 
its interpretation should be that of a surface bustum burial, according to Józefów's classification [16], known as Flächenbusta [19] or, even more probable, as a complex of such features.

In Świerkówiec, county Mogilno, there have been discovered 3 features, quite large, around $2 \mathrm{~m}$ long and over $1 \mathrm{~m}$ wide (with only one being $0.6 \mathrm{~m}$ wide). Their bottom layers were burned and their fills consisted of humus, charcoal and small, quite often burned stones. It is worth emphasising that bone material was absent, while in two of these features fragments of burned pottery were found, and a ritually bent iron knife and an iron awl in the other [29]. It seems that even though no human remains have been found, still these discoveries might be interpreted as cremation sites. However, according to what has been said already, they should be most probably classified as busta rather than ustrina.

In the cemetery in Wymysłowo, county Gostyn, there have been 2 features recorded, interpreted as having been used in a cremation process. The first one, the original size of which is unknown, probably had a cobbled surface where sherds of pottery and fragments of charcoal were found. The second one, very large: $4.10 \times 3.15 \mathrm{~m}$ in size, was located in the neighborhood of the burial. It was built of stones that bear marks of high temperature environment, and between them there have been potsherds and numerous fragments of charcoal recorded. However, no marks of burning of the bedrock have been observed [30], which makes their connection with a cremation process rather questionable. However, the presence of burning does not necessarily mean the high and prolonged temperatures of a pyre. On the contrary, the absence of it does not necessarily mean no contact with fire.

Summing up, it might be said that in 7 cemeteries of the Przeworsk communities in Great Poland (of 212 excavated sites) there have been recorded features that might be described as bustum burials. Nonetheless, it is difficult to be more precise about their individual number and definition. It seems possible only to determine that at least 7 of them were surface bustum burials and more than ten had under-pyre pits. In two other mentioned cemeteries such classification of unearthed and de-scribed features, despite traces of burning, seems impossible in the light of doubts presented above.

When analysing the Wielbark culture materials it must be emphasised that the evidence is scarce as compared to that of the Przeworsk culture. Supposed cremation sites have been recorded only in 2 cemeteries.

Four cremation sites have been recorded in Brójce, county Międzyrzecz. They were large ditches, 2-3m long, 1-1.5m wide, and up to $0.6-0.7 \mathrm{~m}$ deep. Their fills included numerous charcoals, singular fragments of pottery and bones (most probably burned?). In one of these features there has been half-burned timber found and the soil below was strongly burned (orange and red in colour). The structure was surrounded with 6 stones making a regular quadrangle. There might have been even more of them, but they were dispersed [31]. It seems that interpretation of all four features is obvious and they were typical bustum burials with under-pyre pits, according to Józefów [16] and Grubenbusta [19].

The last, quite doubtful, example of a cremation site comes from Słopanowo (burial 54). According to the description pro-vided by the author: "the pit was not clearly seen, either vertically, or horizontally", and "the grave was found in an occupational level dating to the Roman period, and included, except for vessels and fibulae, several human bones, mixed up with fragments of charcoal" [32]. The mentioned settlement, however, had existed earlier than the cemetery under consideration [32]. It seems that what was interpreted as an "occupational level" in fact was an integral part of a stratified burial, and the context resulted from in-situ cremation - thus it would be a surface bustum burial, according to Józefów [16] or Flächenbusta [19].

To sum up the above evidence regarding the Wielbark culture in Great Poland it should be emphasised, as it has already been, that cremation sites, such as bustum burials have been recorded in 2 necropolises (of 112 excavated graveyards). They were 1 hypothetical surface features and 4 obvious bustum burials with under-pyre pits.

The absence of such features within numerous and well-explored cemeteries of the discussed group in Great Poland is the other argument proving the thesis of the existence of areas separated from necropolis and settlements - specially chosen places located elsewhere, where the process of cremation took place. But the most important was that human burned remains were not left there, but were deposited in urns and taken to cemetery by the mourners.

\section{Conclusion}

The situation observed in the Przeworsk and Wielbark cemeteries in Great Poland is polarised. On the one hand within a burial area existed cremation sites like surface bustum burials or these with under-pyre pits, which de facto were graves of people cremated in situ, and referred to the area of sacrum, in which they were deposited (necropolises). On the other hand, there have no ustrina been recorded in this area, also absent within settlements $[2,8]$. The other issue, widely discussed in the literature, is putting the pyre down with water $[16,33,34]$. This might throw some interesting light on the location of ustrina. In Great Poland, according to the results of research, the Przeworsk communities did not locate their cemeteries near water supplies - it was not an important characteristic [35]. Thus, if water seemed important in the cremation process and its presence near cemeteries was not, then there is only one alternative explanation - building ustrina on banks of the rivers (or lakes?). Such a possibility has been already suggested in the literature on the subject [8]. An important argument supporting such an interpretation was a disproportionately low number of cremation sites [2] compared to the number of cremation burials [8]. An extreme disproportion has been observed during research in Great Poland (of Przeworsk and 
Wielbark culture in total), where the number of the latter was 4744, while of the former only slightly more than 20 [1].

Another verification of the hypothesis comes from the analyses by Gorzkowska [8], who proved that the hearths discovered on site 34 in WólkaDomaniowska, county Radom, were in fact single cremation sites. The features (82) were located quite far from two settlements (170 and $320 \mathrm{~m})$, as well as cemeteries $(250 \mathrm{~m})$. Moreover, they have been found on the former river bank as a result of its meandering. Especially important seems the fact that the number of "hearths" is very similar to the number of cremation burials discovered in the neighbouring necropolis. This discovery validates the above hypothesis concerning location of ustrina, at the same time illustrating how small is a chance to find such a site and to interpret it properly.

It should be also mentioned that such a location of ustrina, as well as analogues in Hindu rituals, might suggest a solution to a serious problem concerning burial rituals of the Przeworsk community in the Late Roman period. At that time (since about the half of the third century AD) was observed an abruptly decreasing number of cemeteries and burials of the "Przeworsk-type" recorded both in the area under consideration (Great Poland) and in the neighbouring territories - such as Silesia or central Poland $[17,36,37,38,39]$. The group might have changed their burial rituals into such a form that is not recorded in archaeological evidence $[38,40,41)$. Is it possible that cremation remains were thrown into the river on the banks of which the cremation ceremony took place.

It seems that the thesis presented in the introductory part of the article has been proved by both archaeological evidence, and anthropological observations. There have been found no ustrina within cemeteries, and they should not be expected there. They were constructed on the river banks, far from the eternal resting places. On the other hand, there are bustum burials discovered within necropolises. They throw a new light on their users, whether individuals or groups. They all had their right to be unique, which manifested in various styles, clothes ... and even in the form and rite of a funeral. It seems possible then to suggest that bustum burials reflected some sort of a variety, differentiation from the common idea of the ustrina cremation. The idea might have been based on ethnic differences, meaning that there were strangers living in the Przeworsk or Wielbark communities, who followed their own rites of passage brought together with them. Such kind of a funerary rite and a burial might have been restricted for chosen ones only - someone playing an important social or ritual role. There is no one explanation, and to find it further research is required - more detailed analyses of stratification and structure of the past communities.

\section{Acknowledgements}

In this place I particularly wish to thank Emma-Jayne Graham from The Open University for all help and attention she offered me. I also want to thank Rebecca Gowland and
Joy Eddy from Durham University.

\section{REFERENCES}

[1] D. Żychliński.

Obrządekpogrzebowykulturyprzeworskiejiwielbarskiej w Wielkopolsce. Gniezno, in press.

[2] J. Szydłowski. Z badańkremacji w pradziejach. Metody, wynikiikonsekwencjebadańkości z grobówciałopalnych, 71-76, 1974.

[3] M. Polfer. Reconstructing funerary rituals: the evidence of ustrina and related archaeological structures. Burial, Society and Context in the Roman World, 30-37, 2000.

[4] C. Fowler. The archaeology of personhood. An an-thropological approach. London and New York: Routledge, 2004.

[5] E.-J Graham. Becoming persons, becoming ancestors. Personhood, memory and the corps in Roman rituals of social remembrance. Archaeological Dialogues, 16, 51-74, 2009.

[6] A. van Gennep. Obrzędyprzejścia. Warszawa, 2006.

[7] D. Żychliński. Ogień w obrzędowościpogrzebowej w okresiewpływówrzymskich w Wielkopolsce. Ogień żywiołujarzmionyiżywiołnieujarzmiony, 117-121, 2011.

[8] M. Gorzkowska. Paleniskaodkrytenastanowisku nr $34 \mathrm{w}$ WólceDomaniowskiejkołoRadomia. Próbaokreśleniafunkcji. Kulturaprzeworska. Odkrycia - interpretacje - hipotezy, 1, 123-146, 2004.

[9] A. Kempisty Obrządekpogrzebowy w okresierzymskimnaMazowszu. Światowit 26, 1965.

[10] J. Jaskanis. ObrządekpogrzebowyzachodnichBałtów u schyłkustarożytności (I-V w. n.e.), Wrocław - Warszawa Kraków - Gdańsk, 1974.

[11] E.-J. Graham. From fragments to ancestors. Re-defining osresectum and its role in rituals of purification and commemoration in republican Rome. Living through the dead. Burial and commemoration in the classical world, 91-109, 2009.

[12] M. H. Crowford. Roman Statutes (Volume 1 and 2), London: Institute of Classical Studies School of Advanced Study University of London,1996.

[13] L.V. Thomas. Trup. Łódź, 1991

[14] S. Hamner, A. Tripathi, R.K. Mishra, N. Louskill, S. Broadway, B.H. Pyle, T.E Ford. The role of water use patterns and sewage pollution in incidence of water-borne/enteric diseases along the Ganges River in Varanasi, India. International Journal of Environmental Health Research, 16, 113-132, 2006.

[15] I. McDonald. River of Gods. New York, 2007.

[16] B. Józefów. Typologiaobiektówkremacji w okresierzymskim. $\mathrm{Na}$ przykładachwybranych $\mathrm{z}$ terenówprowincjirzymskichi Barbaricum. Kulturaprzeworska. Odkrycia -interpretacje hipotezy 2, 211-242, 2008. 
[17] J. Szydłowski. ObrządekpogrzebowynaGórnymŚląsku w okresiewpływówrzymskich. RocznikMuzeumGórnośląskiego w Bytomiu, 1964.

[18] T. Bechert. ZurTerminologieProvinzialrömischer Brand-gräber. ArchäologischesKorrespondenzblatt, 10, 253-258, 1980.

[19] J. McKinley. Phoenix rising; aspects of cremation in Roman Britain. Burial, Society and Context in the Roman World, 38-44, 2000.

[20] J. Piątek.

Wpływprocesukremacjinamorfologiękościszkieletuludzkieg o. Wynikibadańeksperymentalnych. Popiółikość, FuneraliaLednickie, spotkanie 4, 95-108, 2002.

[21] J. Skowron. Cmentarzyskoludnościkulturyprzeworskiej w Kunachnastanowisku 4, w Wielkopolscewschodniej. Kulturaprzeworska. Odkrycia - interpretacje - hipotezy 2, $11-210,2008$

[22] Z. Zakrzewski. Cmentarzysko z kulturąrzymską w Ciążeniu, w pow. słupeckim (woj. łódzkie). PrzeglądArcheologiczny, 2, 91-99, 1925.

[23] B. Erzepki. Kurhan w Grunówku pod Lesznem. ZapiskiArcheologicznePoznańskieTowarzystwaPrzyjaciółNa ukPoznańskiego, 1, 37-44, 1888.

[24] A. Karpińska. Kurhany z okresurzymskiego w Polscezeszczególnymuwzględnieniemtypu siedlemińskiego. Poznań, 1926.

[25] H. Kóčka-Krenz. Sprawozdanie z badańwykopaliskowychnacmentarzysku zokresuwpływówrz ymskichiwczesnegośredniowiecza w Koninie, stan. B. Fontes Archaeologici Posnanienses 24, 244-246, 1974.

[26] A. Dymaczewski. Cmentarzysko z okresurzymskiego w Młodzikowie, pow. Środa. Fontes Archaeologici Posnanienses, 8-9,179-443, 1958.

[27] F. Pfützendeiter. Die vor- und frügeschichtlicheBesiedlung des KreisesFraustadt. Schneidemühl, 1933.

[28] E. Pawlak. Cmentarzyskoludnościkulturyprzeworskiej w OsiekukołoJarocina. Wstępnewynikibadań. WielkopolskieSp rawozdaniaArcheologiczne, 12, 295-315, 2011.

[29] E. Bokiniec. Cmentarzysko z młodszegookresu przedrzymskiego w Świerkówcu, gm. Mogilno. COMHLAN - studia $\mathrm{z}$ archeologiiokresu przedrzymskiego irzymskiego $\mathrm{w}$ EuropieŚrodkowejdedykowaneTeresieDąbrowskiej w 65 . rocznicęurodzin, 115-140, 1999.

[30] S. Jasnosz. Cmentarzysko z okresu późnolateńskiego irzymskiego w Wymysłowie, pow. Gostyń. Fontes Praehistorici, 2, 1-282, 1952.

[31] C. Umbreit,. Das GotischeGräberfeld von Brätz Kr. Meseritz. Bonner HeftezurVorgeschichte, 11, 43-54, 1976.

[32] K. Przewoźna. Osadaicmentarzysko z okresurzymskiego w Słopanowie, pow. Szamotuły. Fontes Archaeologici Posnanienses, 5, 60-139, 1955.

[33] J. Szydłowski. Zestudiównadciałopalnymobrządkiempogrze bowymkulturyprzeworskiej. ArcheologiaPolski, 9, 430-451, 1964.

[34] J. McKinley. Cremation . . . the cheap option? Social archaeology of funerary remains, 81-88, 2006.

[35] D. Żychliński. Lokalizacjacmentarzyskkulturyprzeworskiej w Wielkopolsce. Hroby a pohřebištěgermánowmezi Labem a Dunajem, 183-188, 2011.

[36] S. Pazda. Studianadrozwojemizróżnicowaniemlokalnymkult uryprzeworskiejnaDolnymŚląsku. StudiaArcheologiczne 10, 1980.

[37] K. Godłowski. Przemianykulturoweiosadnicze W południowejiśrodkowejPolsce w młodszymokresieprzedrzymskimii w okresierzymskim. Wrocław - Warszawa - Kraków - Gdańsk - Łódź, 1985.

[38] M. Mączyńska. Schyłkowafazakulturyprzeworskiej. KulturaPrzeworska 4, 25-53, 1999.

[39] A. Błażejewski. Obrządekpogrzebowykulturyprzeworskiejna DolnymŚląsku. Wrocław, 1998.

[40] K. Godłowski. Die Barbarennördlich der Westkarpaten und die militärischeKontakte. Specimina Nova. A Pécsi Janus PannoniusTudomänyeegyetemTörtenetiTanszékénekÉvköny ve, Pecs, 65-89, 1994.

[41] T. Makiewicz, W. Kaczor. Pierwszeodkryciegroburowkowe go z okresuwędrówekludówWielkopolsce (Konarzewo, pow. Poznań Ziemski, stan. 5), Folia Praehistorica Posnaniensia, t. XIII/XIV, 245-267, 2005. 